\title{
Macroeconomics for a Modern Economy ${ }^{\dagger}$
}

\author{
By EdMund S. Phelps*
}

Expressionism was rooted in the new experience of metropolitan life that transformed Europe between 1860 and 1930. It [is] a visionary expression of what it feels like to be adrift, exhilarated, terrified in a fast-paced, incomprehensible world.

—Jackie Wullschlager, "The Original Sensationalists," Financial Times

The modern economy began to supplant the traditional economy in several nations in the latter half of the nineteenth century-and in many more in the latter half of the twentieth. A system where selfemployment and self-finance was typical gave way to a system of companies having various business freedoms and enabling institutions. This was the "great transformation" on which historians and sociologists, as well as business commentators, were to write volumes. The modern economy, where fully adopted, has indeed been transformative for $n a$ tions 1 - but much less so for economics.

If there is a thread running through my publications, particularly the work discussed here, it is that I have tried in that work to bear in mind the distinctive nature of the modern economy. ${ }^{2}$ What is its nature?

* McVickar Professor of Political Economy and Director, Center on Capitalism and Society, Earth Institute, Columbia University. For discussions related to this lecture, some of them stretching back decades, I am grateful to Philippe Aghion, Max Amarante, Amar Bhide, Jean-Paul Fitoussi, Roman Frydman, Pentti Kouri, Richard Nelson, and Richard Robb. Raicho Bojilov and Luminita Stevens gave creative research assistance.

${ }^{\dagger}$ This article is a revised version of the lecture Edmund S. Phelps delivered in Stockholm, Sweden, on December 10, 2006, when he received the Bank of Sweden Prize in Economic Sciences in Memory of Alfred Nobel. The article is copyright (C) The Nobel Foundation 2006 and is published here with the permission of the Nobel Foundation.

${ }^{1}$ Several European nations saw rising opposition to modernism in the nineteenth century and proceeded in the interwar period to hamstring their modern economies with the institutions of a twentieth century "corporatist" system of permissions, consultations, and vetoes, making business subservient to community and state.

${ }^{2}$ This recollection focuses on the main works of mine relating to imperfect information and incomplete knowledge. That leaves out several papers, including ones on

\section{Modern Economies and Modern Economics}

Many of the early contrasts between the two kinds of economy were drawn by sociologists. The traditional economy was said to rest on a community of persons known to one other and engaged in mutual support-on Gemeinschaftwhile the modern economy was said to be based on business, where people competed with one another-on Gesellschaft (Ferdinand Tönnies 1887). ${ }^{3}$ Social rank was said to count in a traditional economy but not in a modern economy (Weber, 1921-22). True or not, these sociological contrasts did not obviously call for a fundamental revision of standard economic models.

Economic contrasts between the two systems were drawn by economic historians. A traditional economy is one of routine. In the paradigm case, rural folk periodically exchange their produce for goods of the town. Disturbances, if any, are not of their doing and are beyond their control-temperature, rainfall, and other exogenous shocks. A modern economy is marked by the feasibility of endogenous change: modernization brings myriad arrangements from expanded property rights to company law and financial institutions. That opens the door for individuals to engage in novel activity in the financing, developing, and marketing of new products and methods-commercial innovations. The emergence of this "capitalism," as Marx called it, in Europe and America ushered in a long era of stepped-up innovation from about 1860 to 1940; further

risky wealth accumulation, and factor-saving bias in technical change.

${ }^{3}$ Tönnies writes of the "anonymity" of transactors in Gesellschaft, that is, capitalism. That is a fair observation of classical perfect competition. But in my work on modern economies the entrepreneur, financier, manager, employee, and customer are not exactly anonymous. Firms acquire employees who are identifiable and nonsubstitutable; firms know their customers; customers know their supplier; and so on. 
waves of innovation have since occurred. The innovations undertaken were successful often enough that rapid cumulative economic change followed.

A few pioneering theorists, mostly from the interwar years, saw the commercial innovativeness and the ongoing economic change as having systemic effects that altered people's experience in the economy.

- Innovativeness raises uncertainties. The future outcome of an innovative action poses ambiguity: ${ }^{4}$ the law of "unanticipated consequences" applies (Robert K. Merton 1936); entrepreneurs have to act on their "animal spirits," as John Maynard Keynes (1936) put it; in the view of Friedrich Hayek (1968), innovations are launched first, the benefit and the cost are "discovered" afterward. The innovating itself and the changes it causes make the future full of Knightian uncertainty (Frank H. Knight 1921) for noninnovators, too. Finally, since innovation and change occur unevenly from place to place and industry to industry, there is also uncertainty about the present: what is going on elsewhere, much of which is unobserved and some of it unobservable without one's being there. Thus, even if every actor in the modern economy had the same understanding ("model") of how the economy works, one would not suppose that others' understanding is like one's own. With modernization, then, another feature of a traditional economy-common knowledge that a common understanding prevailed-was lost. $^{5}$

- Innovativeness also transforms jobs. As Hayek (1948) saw, even the lowest-ranking employees come to possess unique knowl-

\footnotetext{
${ }^{4}$ Ambiguity and vagueness come into use with papers by Daniel Ellsberg (1961) and William J. Fellner (1961).

${ }^{5}$ I do not mean to suggest that the modern economy has led to a net increase in total risk, measurable and unmeasurable. My sense is that much of the huge gain in productivity was brought by modernization rather than scientific advance and this gain has in turn permitted more and more participants to take jobs that offer reduced physical dangers and moral hazards. Financial innovations have helped to reduce the risks created by modernization. It is plausible that the wide swings in business activity that finance capitalism imposes are no worse than the waves of famine and pestilence that afflicted traditional economies.
}

edge yet difficult to transmit to others, so people had to work collaboratively. Managers and workers, too, were stimulated by the changes and challenged to solve the new problems arising. Alfred Marshall (1892) wrote that the job was for many people the main object of their thoughts and source of their intellectual development. Gunnar Myrdal (1932) wrote that "most people who are reasonably well off derive more satisfaction as producers than as consumers."

Far into the twentieth century, though, economics had not made a transition to the modern. Formal microfounded economic theory remained neoclassical, founded on the pastoral idylls of Ricardo, Wicksteed, Wicksell, BöhmBawerk and Walras, right through the 1950s. Samuelson's project to correct, clarify, and broaden the theory brought into focus its strengths $;{ }^{6}$ but also its limitations: it abstracted from the distinctive character of the modern economy-the endemic uncertainty, ambiguity, diversity of beliefs, specialization of knowledge, and problem solving. As a result it could not capture, or endogenize, the observable phenomena that are endemic to the modern economy-innovation, waves of rapid growth, big swings in business activity, disequilibria, intense employee engagement, and workers' intellectual development. The best and brightest of the neoclassicals saw these defects but lacked a microtheory to address them. To have an answer to how monetary forces or policy had an impact on employment, they resorted to makeshift constructions having either no microeconomics behind it, such as the Phillips curve and even fixed prices, or to models in which all fluctuations are merely random disturbances around a fixed mean.

After some neoclassical years at the start of my career, I began building models that address those modern phenomena. So did several other young economists during that decade of ferment, the 1960s. ${ }^{7}$ At Yale and at RAND, in part

\footnotetext{
${ }^{6}$ One could argue that his textbook (1948) and Foundations (1947) began a Restoration that saved the economics heritage from the radical Keynesians, institutionalists, and behavioralists of that time.

${ }^{7}$ Kindred spirits tilling the field or adjacent fields in the 1960s include Robert Clower, Robert Aumann, Brian
} 
through my teachers William Fellner and Thomas Schelling, I gained some familiarity with the modernist concepts of Knightian uncertainty, Keynesian probabilities, Hayek's private know-how and $M$. Polanyí's personal knowledge. Having to a degree assimilated this modernist perspective, I could view the economy at angles different from neoclassical theory. ${ }^{8}$ I could try to incorporate or reflect in my models what it is that an employee, manager, or entrepreneur does: to recognize that most are engaged in their work, form expectations and evolve beliefs, solve problems and have ideas. Trying to put these people into economic models became my project.

\section{Expectations in Models of Activity}

Unemployment determination in a modern economy was the main subject area of my research from the mid-1960s to the end of the 1970s, and again from the mid-1980s to the early 1990s. The primary question driving my early research was basic: Why does a surge of "effective demand," that is, the flow of money buying goods, cause an increase in output and employment, as supposed in the great book by Keynes (1936)? Why not just a jump in prices and money wages?

Another question arose immediately: How could there be positive involuntary unemployment in equilibrium conditions-more precisely, along any equilibrium path? The answer implied by my model was that if there were not positive unemployment, employee quitting would, in general, be so rampant that every firm would be trying to out-pay one another in order to cut the high training outlay that comes with high turnover. To my mind, the argument did not rest on the "asymmetric information"

Loasby, Armen Alchian, Axel Leijonhufvud, Richard Nelson, Sidney Winter, Arthur Okun, and William Brainard. They were joined in the 1970s and 1980s by Roman Frydman, Steven Salop, Brian Arthur, Mordecai Kurz, and Martin Shubik. In the 1990s and 2000s, Amar Bhidé and Alan Kirman joined in and both Thomas Sargent and Michael Woodford tested the waters.

${ }^{8}$ I did not explicitly put in these modernist concepts into models so much as I took out some neoclassical properties so that the models might be more consonant with modern thinking. premise that a worker could conceal his or her propensity to quit from an employer. (Employers might know better what quit rates to expect than the employees themselves.) It rested on the impossibility of a contract protecting the employer from all the excuses for quitting the employee might be able to claim. There are also the abuses the employer could inflict on employees to force them to quit. In a modern economy, therefore, agreements are unwritten, thus informal, or, where written, not entirely unambiguous.

My approach to the relation between "(effective) demand" and activity started from the observation that, faced with all sorts of innovations and change, the market place of the modern economy was not just "decentralized," as neoclassical economists liked to say. The beliefs and responses of each actor in the economy are uncoordinated: Walras's deus ex machina, the economy-wide auctioneer, is inapplicable to a modern economy in which much activity is driven by innovation and past innovation has left a vast differentiation of goods. This led to the point that the expectations of individuals and thus their plans may be inconsistent. Then, some or all persons' expectations are incorrect - a situation Marshall and Myrdal called disequilibrium. ${ }^{9}$ Thus the economy-say, a closed economy, for simplicity-might often be in situations where every firm (or a preponderance of firms) currently expects that the other firms are paying employees at a rate less than, or perchance greater than, its own pay rate. In the former example, every firm believes that, with its chosen pay scale, it is out-paying the others.

In my first model, having a labor market capable of disequilibrium (Phelps 1968a), the effect of such an underestimate of the wage rates being set elsewhere is to damp the wage rate that every such firm calculates it needs to pay in order to contain employee quitting by enough to minimize its total cost (at present output) - the sum of its payroll costs plus turnover costs. In terms of a later construct, the

\footnotetext{
${ }^{9}$ Imaginably, random forces might come to the rescue, but the expectations would still be incorrect ex ante. In my modeling, I always excluded such random forces for the sake of clarity-forces that are the essence of the New Classical model.
} 
"wage curve" is lowered by firms' underestimating what will be the going wage at their competitors. ${ }^{10}$ Such a lowering of the wage curve serves to lower firms' cost curves, thus to lower the prices and, through the monetary block of the 1968 model, to increase output (achieved at first by moving employees from training to producing); employment gradually expands thanks to reduced quitting caused by employee expectations that wages are lower at other firms than at their own. Later, firms may step up hiring (from the initially reduced level) in response to the reduced costs and thus higher profit margins. What seemed to be a simple model was quickly revealed to be full of subtleties, so that very few students fully master it. However, the point that expectations matter for wages, prices, and activity has been grasped. The economy is boosted by underestimation of competitors' wages and by firms' underestimation in customer markets of their competitors' prices (Phelps and Sidney G. Winter, Jr. 1970). Similarly, the economy is dragged down by overestimation.

What would happen in this economy, with its potential for disequilibrium and, say, increased disequilibrium, if aggregate demand shifted onto a higher path? ${ }^{11}$ I often studied an unidentified spending shock in the private sector that operated to increase the velocity of money and, if the central bank were slow to respond, would drive both the price level and money-wage level toward correspondingly higher paths-whether promptly or in a drawn-out process. I supposed that this velocity shock would be neutral for quantities and relative prices if and when firms and workers formed correct expectations of the

\footnotetext{
${ }^{10}$ See Carl Shapiro and Joseph E. Stiglitz (1984). Guillermo Calvo and Phelps (1983) derived a wage curve in a contract setting.

${ }^{11}$ I was always aware that, in the version of the model in which all firms are ready at the drop of a hat to jump their money wages and prices, there being no setup costs of doing so, a demand shock in a few cases might theoretically have no effect on quantities and relative prices. Take a sudden announcement by the central bank that it is immediately doubling the money supply. If that shock is very public (it could not be missed by anyone) and its consequences are common knowledge, and if it is neutral for equilibrium values, there would result in the models I was studying an immediate doubling of money wages and prices; both output and employment would be undisturbed. Keynes (1936) also implicitly noted such exceptions.
}

money-wage and price responses to the upward shift in the demand price. ${ }^{12}$ Yet firms and workers have no way of perceiving such neutrality at the start.

What ensues? My models implied the following: ${ }^{13}$ every firm mistakenly infers that, as often happens, all or much of the increase in demand it observes is unique to it; so in deciding how much to raise its wage it is led to underestimate the rise of wage rates at the other firms. Similarly, every customer-market firm, in deciding how much to raise its price, is led to underestimate the extent to which the other firms are going to raise their price. As a result, the firm raises its price relative to what it believes the others are going to do but by little - by less than it would do if it did not underestimate the rise elsewhere and less than the increase in its demand price; similarly it raises its wage but by little-by less than it would do if it did not underestimate the rise elsewhere. I added that "uncertainty" might induce a "cautious, gradual response in the firm's wage decision" (Phelps 1968a, 688). ${ }^{14}$

Regarding quantities: the increase at each firm in customers' demand sparked by the velocity shock causes the firm to recognize that, at the initial price and output, it can now sell more without having to lower its price. The firm, which was indifferent about a small increase of output before, sees the profitability of an increase, so it steps up its output. ${ }^{15}$ Hence, there is an increase in the maximum stock of job-ready employees that the firm would retain in their entirety, thus an immediate jump in its vacancies. Accordingly, the decreased quitting brought about by perceptions of an improved relative

\footnotetext{
12 This means that whatever the equilibrium employment path leading from the economy's initial state, the velocity shock is neutral for that equilibrium path and every other equilibrium path, whether attained or not.

${ }^{13}$ I am referring here to a fusion of my 1968 paper with Phelps-Winter (1970) and I am drawing on analyses and commentary in Phelps et al. (1970), Phelps (1972a), and Phelps (1979).

${ }^{14}$ It would be incorrect to infer that the quantity effects of effective demand shifts are present because a sort of wage "rigidity" is imposed in the end. There would be quantity effects anyway, though smaller and maybe less prolonged.

${ }^{15}$ If, as in my 1968 paper, every firm raised its price fully so as to clear the market for its initial output, the increased profit margin would have the same effect.
} 
wage is not a reason for the firm to hire more slowly, so employment expands. As for the hiring response, there is a hitch. The firm could dip into the unemployment pool to acquire any amount of new employees, but obtaining a jobready employee requires diverting current employees from production to give the necessary job-specific training to the new recruit. In stepping up output, however, the firm actually moves employees out of training into production. Thus, increasing hiring has to wait until the decrease in quitting has allowed the firm to restore and then enlarge its training staff. ${ }^{16}$

The above are the impact effects of the demand shift. An adjustment process follows. In my models, a firm would, at some point, notice that its cumulative price increase had not cost it any of the erosion of its customer base it had expected and its wage increase was not bringing it any of the reduced quit rate it had expected. Moreover, following the initial impact of the velocity shock on demand prices, any firm supplying a specialized assortment of goods would experience a secondary increase in its demand price (at the initial output) since the initial price increases, all of them about the same size, do not generally have the substitution effect that the firm had worried about when it calculated its first responses. Owing to all this "learning," firms will raise their prices and wages again, bringing price and wage levels nearer to their equilibrium levels. Even if expectations of the inflation rate remain nil, prices and wages will go on rising until the magnitude of the disequilibrium - the shortfall of the cumulative proportionate increase of the price level from the proportionate increase of velocity-has been eroded to the vanishing point. Along such a path, the shrinkage of wage underestimation reverses the decrease of quitting that powered the employment expansion, leaving the drain of the unemployment pool to cause a net elevation of the quit rate; and the shrinkage of both price and wage underestimation removes the firms' desire for an elevated level of employment, so hiring does not increase to offset the increased attrition. Thus, attrition works off the increase

\footnotetext{
${ }^{16}$ Overtime arrangements with employees are another way, of course, by which the training staff can be spared and even increased in order to permit a step-up in hiring.
}

in employees now seen to be redundant. The price level as well as the real wage and employment are all driven to their new rest-point values. This recovery represents "equilibration" in the sense that expectations of the cumulative increase of the wage level and of the price level are brought into line with actual increases. (But the starting point, thus also the rest point, might not be full-fledged expectational equilibria, since expectations of wage or price levels may be wide of the mark in both states.)

Yet my 1968 paper suggested that from each elevated employment level (such as those reached during the expansion) there exists an equilibrium path back to the initial state, a path along which not only has the underestimation of the increase in wages and prices vanished but, in addition, the expected increase of the wage level and of the price level is just matched by the actual increase. Along any such path, the currently low (but subsiding) unemployment is continuously counter-balanced by the currently low (but subsiding) vacancy level so that firms are trying neither to outpay nor underpay one another. ${ }^{17}$ In this respect, the subsequent model by Robert E. Lucas, Jr. (1972) differed from my work in that it has the tight implication that, following the disturbances of the current Lucas period, the economy immediately jumps to equilibrium as a consequence of his imposing "rational expectations." 18 In my thinking, market

\footnotetext{
${ }^{17}$ Along this path the expected money-wage level is always that necessary, given the expected price level, for "labor market equilibrium" and the expected price level is always such, given the expected wage level, as to satisfy the condition for "product market equilibrium." An explicit analysis of this equilibrium path for a nonmonetary model without a customer market is Hian Teck Hoon and Phelps (1992). An analysis of this path upon making the product market a customer market can be found in Phelps, Hoon, and Gylfi Zoega (2005) and Hoon and Phelps (forthcoming).

It should be added that for labor-market equilibrium there is another condition and corresponding equation. The firm has to get right the shadow price it attached to having another job-ready employee, thus to get right its calculation of its vacancies. This implies that the firm has correct expectations about the level to which market wages are heading over the near term, which in turn means correct expectations about the rate at which wages at the other firms are going to be rising over the near future, not just their current level.

${ }^{18}$ This is jumping to a point in Lucas's model, which is analogous to jumping onto the equilibrium knife-edge path
} 
participants might at any time be able to walk the tightrope of the equilibrium path, if such exists, that leads from where they are currently to their initial state; but, in general, they cannot be presumed to find their way along such a path.

\section{A. Relation to "Rational Expectations"}

The framework above is not a closed system. It does not deliver a fully determined steady state and is not intended to. The current level of vacancies has an exogenous structural component that is a function of what the managers guess to be the right value (i.e., shadow price) to put on having another employee; and that shadow price is variable, not determined by the model. If that value jumps up, owing to impressions of some or all entrepreneurs that future prospects have brightened, vacancies increase and hiring will pick up-apparently out of the blue. ${ }^{19}$ This feature saves the model from being a mechanical apparatus leaving no room for innovation and resulting structural change. ${ }^{20}$

In the model as best interpreted, the firms, in figuring their desired wage target, have to form expectations of the average wage at competitors without benefit of recent publication (let alone observation) of these special wage rates. ${ }^{21}$ So, in general, the labor market is groping not toward equilibrium, in which the belief about the wage at competitors is equal to their actual wage, but toward a surrogate equilibrium in

in my model. In Lucas's period model, there is a Lucas period: before its end no national data are available and at its end all the national data are published. In my continuoustime models there might be lagged data on wage inflation, etc., but not on wage levels, certainly not on levels at comparator firms. (In fact, firms can form associations to share such data and workers might form unions; but I had in mind a "free market" economy without these interventions.)

${ }^{19}$ Keynes's "general" theory was general in taking entrepreneurs' visions as floating - as arbitrary. The arbitrariness of these visions is important for the firm's wage contract in Calvo and Phelps (1977).

${ }^{20}$ The model's projection of the economy's future path is contingent on constancy of the exogenous part of the vacancy function, though the actual path may well be disturbed by exogenous changes in vacancies.

${ }^{21}$ At some places in my papers, the mean wage level is taken to be known, as if recently published, but only in a variant model with a fixed wage commitment over some interval of the future. (Such a point is on p. 701 in Phelps 1968a.) Otherwise the wage is not known but is inferred from unfolding circumstantial evidence. which expectations might, say, underestimate the actual wage level (Phelps 1972). Then the unemployment rest point, given the same vacancy rate, is below that steady-level consistent with (expectational) equilibrium. (Of course, the gap between perception and reality is changeable.)

Last but not least, positing rational expectations equilibrium is not just inaccurate as a way to close the model in the same sense as postulating rational choice is taken to be inaccurate: it is inappropriate to impose on the model. In a highly innovative economy and thus one subject to change, firms - even firms in the same industry and location-are all thinking differently. So a firm would have no grounds to reason, as it implicitly does in rational-expectations theory, that "since I have calculated I must raise my wages by $x$ percent, I should now take into account that my competitors are planning to do the same; so I must now adjust my wage increase even more ...." This kind of inductive reasoning to arrive at the right expectations is inapplicable. That is the thesis of my piece (Phelps 1983) in the Frydman-Phelps volume (1983).

More fundamentally, the public cannot form "rational expectations" about future probability distributions when the future is being created currently by the new ideas and consequent plans of entrepreneurs to which the public has no access and of which the entrepreneurs themselves are uncertain (Calvo and Phelps 1977). If firms are engaging in creative activity, "running regressions" on past data will not give a firm an applicable prediction of what these firms are planning now to do in any respect (see Frydman and Michael D. Goldberg, forthcoming). Understanding KeynesFellner probabilities for use under uncertainty, one gives less weight to historical projections of what they are up to when one understands that they are preparing a surprise.

So, if asked whether my theory was superseded by the Lucas model, I would have to say that if an economy possesses dynamism, so that fresh uncertainties incessantly flow from its innovative activities and its structure is everchanging, the concept of rational-expectations equilibrium does not apply and a model of such an economy that imposes this concept cannot represent at all well the mechanism of such an economy's fluctuations. 


\section{B. Relation to Friedman's 1968 Model}

The theory above of the "natural rate" and deviations from it driven by misunderstood shifts and disturbances is often taken to be essentially identical to that presented by Milton Friedman (1968). The two models are then treated as simultaneous discoveries of the same thing. In fact, they represent discovery of two distinct phenomena. Friedman's is a model of the natural rate of labor force participation, while mine is a model of the natural rate of unemployment. Myriad differences derive from that distinction. For example, in the former model an unperceived increase in demand is an unwelcome deviation from competitive equilibrium, while in mine it moderates a generally onerous volume of involuntary unemployment. (Below I will comment briefly on a monetary policy aimed at high employment.)

\section{Relation to Keynesianism}

Some have kindly commented that this work and related work in the Microfoundations volume (Phelps et al. 1970) was "revolutionary" (Pissarides 2006; Samuelson 2006). Two comments cry out to be made, however. One is that my sort of micro-macro modeling left standing some of Keynes's core beliefs: Effective demand shifts, even "neutral" ones, typically impact on business activity. Furthermore, the price level and the money wage level are not perfect in equilibrating markets. ${ }^{22}$ On the other hand, my subsequent research endogenizing the natural unemployment rate has since dissociated me from some other core parts of the Keynesian policy position.

\section{Use in a Theory of Optimum Monetary Policy}

The first published application of this expectational framework was in modeling the optimal inflation policy (Phelps 1967). ${ }^{23}$ This was a reaction to the emerging application of the Phil-

\footnotetext{
${ }^{22}$ Scholars unearthed for posthumous publication (Keynes 1983) a draft chapter by Keynes entitled "The Uncoordinated Economy," and James Tobin, the leading American Keynesian, wrote that Keynes's theory was about "expectational disequilibrium" (Tobin 1975).

${ }^{23}$ This paper was written at the London School of Economics in the early months of 1966 before I tackled the
}

lips curve (Alban William Phillips 1958) in modeling the "optimum" inflation rate (Okun 1965). There were times when this 1967 paper seemed to me to have been bypassed by the rational expectations-based Taylor rule (John B. Taylor 1993, 1999). Yet my paper has continued to bear fruit in studies of historical disinflations (Sargent 1999). The Nobel Prize committee (2006) cited my research viewing policymaking from an intertemporal perspective. So I want to touch on that paper, which will be the main subject of the next section.

\section{Policy to Alter Undesired Expectations}

My earliest work on policy from an intertemporal point of view was about fiscal policy in a moneyless economy. In Phelps (1965) my premise was that, in general, the public might expect the present discounted value of their "lifetime" tax liability to be less than was foreseeable. (I cited David Ricardo in defense, some years before "Ricardian" came to denote what he rejected.) The result, according to the model there, would be an overdemand for consumer goods and an undersupply of labor to the market economy. A policy of "fiscal neutrality" would align the expected lifetime tax liability in present value terms to the expenditures and transfers that the government expected to make. If the public did not possess rational expectations, tax rates would be set either higher or lower than would otherwise be necessary for neutrality. Thus was born the thought that market expectations matter for supply and they may be undesirable, so an "optimal" policy would correct such expectations.

The key premise of the 1967 paper was that the public's expectations of the inflation rate might be undesirably high and that the only way the government authorities could induce the public to lower its expectations was to disappoint those expectations by forcing the actual inflation rate to be lower than the expected inflation rate- until the expected rate is down to the acceptable level. Another premise was that unexpected inflation brings above-natural employment and unexpected disinflation brings

subjects of the 1968 and 1970 papers on wage dynamics and price dynamics. 
below-natural employment, that is, above-natural unemployment; thus "disinflation," as I later called it, would entail a transition cost: the cost, economic and social, of a transitory bulge of the unemployment rate above the natural level, which could be realized if the authorities were to resign themselves to ratifying current inflation expectations by setting effective demand as to realize the natural unemployment rate. These ideas were then imbedded in a setting formally like the familiar model of optimum capital accumulation by Frank P. Ramsey (1928). The expected inflation rate, $x$, takes the role of the state variable played by the capital stock in Ramsey's model; the deviation of the actual inflation rate, $f$, from $x$ is analogous to the deviation of consumption from income. In this exploration, the policy variable was fiscal-the demand level brought about by the size of the balanced budget, which leaves the public debt constant-and monetary policy stabilized investment demand so as to keep constant the capital stock. The analysis (done in 1966) did not go very easily and in my later book (Phelps 1972a), done in 1969-70, the problem was simplified: inflation policy was conducted by the monetary authority and fiscal policy is supposed to neutralize effects on capital and public debt. In brief, the problem is to find the policy function $f(x)$ that maximizes the possibly discounted utility integral subject to the differential equation $d x / d t=\beta(f-x), \beta$ a positive pseudo-constant.

The results: if the expected inflation rate is greater than (less than) the rest point level to which an optimal policy will bring it down, so there is a gap to be filled, an optimal policy always requires driving the inflation rate below the currently expected rate, no matter the shortterm gain. The greater the initial excess of the expected inflation rate over its rest point, of course, the greater is the size of the optimum deviation of actual inflation from expected inflation-and thus the greater is the initial increase in unemployment. The smaller is the utility discount rate, the lower is the rest point target for the expected inflation rate and the greater is the optimum size of the initial shortfall-the greater, then, the near-term pain and the long-term gain. The greater is the costliness of decreased employment, the smaller is the optimum initial deviation-the smaller, then, the optimum deviation of unemployment from its natural level-and thus the slower the speed of the disinflation.

Looking back, it may be that my 1967 paper was the father of what came to be called inflation targeting. ${ }^{24} \mathrm{I}$ was aware, however, of a complication standing in the way of so simple a characterization of optimal monetary policy. In the last pages of the uncondensed discussion paper from which the published paper was extracted (Phelps 1966c), I examined a richer model in which the unemployment rate, $u$, is sluggish (as in my 1968 paper) and is thus an added state variable alongside the expected inflation rate. Then the optimal policy function, $f(x, u)$, does not generally drive the expected inflation rate monotonically toward its rest point level. An initial unemployment rate far above or below its natural level may drive the optimal inflation rate above or below the expected inflation rate even if the latter is currently at its rest point level. But this expected rate will sooner or later loop back to its rest point while the unemployment rate goes to its rest point, the natural unemployment rate. The interest rate rule made famous by Taylor (1993) has the same character, although it derives from optimizing policy in a different sort of problemoptimal stabilization of the inflation and unemployment rates around their means under "rational" expectations.

It might also be said that my 1967 and later works planted the idea that the function of the central bank is the management of inflation expectations-the idea that if the central bank will monitor and stabilize the expected inflation rate, the actual inflation rate will not get out of hand for long. Parametric shifts may drive the price level onto a different path but they will not permanently alter the trend growth rate of the price level. (I myself may have thought that.) In an economy operating under imperfect knowledge of the economy's future prospects, there is always the possibility that the central bank will seriously misestimate the natural real interest rate. In that case, the central bank's interest rate rule does not start off with the right constant

\footnotetext{
${ }^{24}$ Perhaps the earliest interest rate rule is that in William G. Dewald and Harry G. Johnson (1963) but their rule does not drive any variable, such as the inflation rate, to a target level. Neither do the proposed money supply rules.
} 
term from which the real interest rate set by the bank is to deviate in response to a discrepancy between the expected inflation rate and the target rate. If the natural real rate is underestimated while everything else is perfectly gauged, the bank will set its real rate too low to hold inflation at the level it intended (Phelps 2006b).

I would make another comment based on the imperfect knowledge of participants. Some advocates of rational expectations complain about expectations that are adaptive, as in my 1967 model (Lucas 1976). The discussion of "routine stabilization" in chapter 8 of my 1972 book recognizes that expectations will not be adaptive in any rigid way in the face of identical repetitions of the same experience and struggled for awhile with what to do. (The coefficient could not be a genuine parameter, fixed from disinflation to disinflation.) Yet this point is not sufficient to establish the aptness of the postulate of rational expectations. ${ }^{25}$ Dynamic economies do not have identical repeated games ("one never stands in the river at the same place twice," as the Chinese say), there is a diversity of opinion in markets, and a policymaker does not fall into one of a fixed set of types. (Even Paul Volcker had to earn credibility.) Keynes believed that market players' expectations cling to the latest model until contrary evidence has piled up enough to shatter that model and open the way to a new model and radically different expectations. The adaptive expectations equation is an approximation of such a process.

\section{Structuralist Models of Natural Rate Swings and Shifts}

The long swings and large shifts of the unemployment rate without rising inflation or disinflation that have been observed over the past several decades in OECD countries-and, for that matter, the formidable intercountry differences in unemployment rate-suggest that pow-

\footnotetext{
${ }^{25}$ I was glad to explore with John Taylor and later Guillermo Calvo the rational expectations-based New Keynesian modeling of wage and employment determination in research done at Columbia in the 1970s (see Phelps and Taylor 1975, and Phelps 1978). However, I did not believe that the rational expectations premise was satisfactory or even clearly preferable to some flexible use of adaptive expectations.
}

erful forces have had an impact on the natural unemployment path itself. Indeed, many scholars in the early decades of the twentieth century sought to explain booms and crises in terms of real market forces rather than monetary forces. Any adequate explanation of the failure of the unemployment rate to regain its pre-bull-market level in the mid-1920s almost certainly requires a theory to "endogenize" the natural rate.

A nonmonetary theory of the (path of the) natural unemployment rate began to develop in the 1980s built on the same employee training model and the customer market model I had used in the 1960s. An austere exploration in that direction (Calvo and Phelps 1983) focused on time preference and wealth, but lacked unemployment. Some two-country modeling (JeanPaul Fitoussi and Phelps 1986, 1988) focused on overseas interest rates and exchange rates but it lacked a natural rate. Closed- and openeconomy models with the desired features emerged in a series of research papers from 1988 through 1992 and in a volume (Phelps 1994) with the substantial help of Hian Teck Hoon and Gylfi Zoega. ${ }^{26}$ This was a more radical rewrite of macroeconomics than my micromacro research in the late 1960s. The theory showed how wealth in relation to after-tax wages and to productivity has an impact on the propensity to quit and thus the incentive-wage curve; the world real rate of interest, future prospects, and some other forces have an impact on the shadow price firms place on their business asset-employee or customer; and these impacts disturb or permanently alter the natural rate itself (Phelps 1994). I loved this theory. It depicts increases in the overseas real rate of interest as contractionary, contrary to the Keynesian Hicks-Mundell-Flemming model (where "velocity" is stimulated) and contrary to the neoclassical Hicks-Lucas-Rapping model (where labor supply is increased). A real exchange rate depreciation caused by overseas events would over some range of parameters lead to contraction, gradually attenuated by a gain of customers, contrary to Keynesian thinking.

\footnotetext{
${ }^{26}$ Some of the many papers from that period and further developments include Hoon and Phelps (1992), Phelps (1992), Zoega (1993), Hoon and Phelps (1997), Phelps and Zoega (1997), and Phelps and Zoega (1998). Some precursors are Phelps (1972b) and Steven C. Salop (1979).
} 
This supplementary theory makes clear how three structural forces in the 1930s may have pushed up the natural unemployment rate: ${ }^{27}$ First, the specter of war hung over the United States as well as Europe in the second half of the 1930s, which must have damped investment activity, including acquiring new employees (Phelps 2006c). Second, the Social Security Act reduced after-tax wages, yet in turn reduced private wealth - a nullifying effect; but it created "social wealth," which has net contractionary effects (Hoon and Phelps 1996; Hoon 2006).

Finally, my models to study "structural booms" showed that the sudden emergence of new prospects for innovation, in raising the shadow prices, would induce firms to hire and train an increased number of employees in anticipation of the rise of productivity; its actual arrival raises the opportunity cost of investing in employees and customers (Fitoussi et al. 2000; Phelps and Zoega 2001). In this view, the 1930s soar of productivity was largely not an expansionary force; it was the anticipated fruit of the earlier investment boom and largely contractionary. For me, this was revelatory work, as it saw the well-functioning capitalist economy as driven by unseen and visionary forces springing from the creativity and opportunity of business people-forces that cannot be imagined to obey any stationary stochastic formula (Phelps $2006 \mathrm{~b})^{28}$ —nor indeed any predeterminable stochastic formula (Frydman and Goldberg 2007).

To sum up: the completed theory of activity that incorporates the modeling of natural unemployment into the 1960s modeling described above says that employment increases in either or both of two ways-increased effective demand lifts employment off its present equilib-

\footnotetext{
${ }^{27}$ It is worth mentioning that the extraordinary technical changes over the whole decade must have increased "frictional" unemployment, although the latter is outside my models.

${ }^{28}$ There is a touch of rational expectations in my supposing that after a shift in the economy's structure or future prospect the prices and quantities follow a perfect foresight path. But that foresight is conditional on the absence of further shifts in the future, while the model does not promise such shifts will not occur. The economy's participants may very well be conscious of the possibility that the future will not hold further shifts. But they do not know what parameters shifts to anticipate and what their effects will be. That may be only a crude approximation to ignorance of the future, but it may be better than no approximation at all.
}

rium path and actual money wages climb above their expected path or an upward shift of natural employment pushes up actual employment, though by less than the natural increase, and actual wages are driven below their expected path. In the past 30 years the focus of attention has swung away from effective demand shifts and swings under the tacit assumption that the natural rate of unemployment had moved little and toward shifts and swings of the natural rate itself under the tacit assumption that effective demand is not a problem, at least not when the central bank has a good monetary policy. We would not have gotten to this level of understanding had it not been for the development of both the monetary and the structuralist elements of the complete theory.

\section{The Business of Growth}

In neoclassical economics, the objects of the theory were not human endeavor as we know it-only "prices and quantities." There was a disconnect from history and the humanities. Neoclassical growth theory was conspicuous in having no people in it. It explained the accumulation and investment of physical capital, yet the driving force in that story-increases in knowledge, called "technology"-rains down exogenously, like manna from heaven-and the selection among new technologies is instantaneous, costless, and error-free. Though in fact crucial for growth, a human role over a vast range of activities involving management, judgment, insight, intuition, and creativity is absent.

Nowhere was that character of neoclassical theory more evident than in the theory of national saving. The model by Ramsey (1928) was the prime example and another was my neoclassical model of risky wealth accumulation (Phelps 1962). At the University of Pennsylvania I thought it might be fruitful to stop modeling the nation as a sort of infinite-lived "single agent" and imagine instead a sequence of generations of people connected by bequests. The paper by Phelps and Robert A. Pollak (1968) solved the puzzle of how much each generation would save in "game equilibrium" and confirmed that more is involved in the saving decision than technocratic considerations: the rate of time preference and the rate of return to 
saving. Each generation's selfishness also matters (see also Phelps 1973). ${ }^{29}$

In another paper I explored the idea that technological progress requires the allocation of people to research (Phelps 1966b). A technical progress function described the relationship between the rate of technological progress and the magnitude of the research activity. To be sure, the larger the size of the research input maintained over the years, the faster will be the climb of the technology variable. Yet the proportionate rate of progress is diminishing, even if the absolute gain per unit time is increasing. I began investigating whether an increasing volume of research effort through time could stave off the slowdown of the rate of progress. I found that, with a suitable specification of the progress function, exponential growth of the research input would lead gradually to exponential growth of the technology variable. This led rather quickly to the uncovering of two implications, both of them intriguing.

An obvious implication was that the higher the level of the exponential growth path of the research input, the higher would be the level of the exponential growth path to which the path of the technology variable would approach. To a novice, then, it would seem that the greater the effort society puts into research the better. But economists care also about consumption-indeed some care only about that. I built a simple model in which consumption was produced (using the current technology) by all the population who did not do research. I found that up to a point the greater the ratio of research input to nonresearch input, the higher the level to which the consumption path would approach. But after that point further increases in that ratio would actually decrease consumption, since the gain in technology achieved would not repay the cost of pulling labor out of producing the consumer good. This was another Golden Rule for my collection of such rules (Phelps 1961, 1966a). A strange thing was that one could put a number to the ratio. It is equal to one: one researcher for every producer.

The other implication was that a larger

\footnotetext{
${ }^{29}$ Later David Laibson (1997) applied the theory to a person having future selves distinct from the present self.
}

population would provide a larger number for research and thus permit a climb onto a higher technology path (Phelps 1968b). The historical applications are obvious. Had it not been for the vast population increase beginning in the eighteenth century and only now winding down, the number of minds could have achieved only a small proportion of the colossal technological advance of the past two centuries. So we can be grateful for the population explosion-my Mozart Proposition, as it was called. On this logic, economic growth in the twenty-first century will be faster than in the twentieth.

No one standing at the threshold of the eighteenth century could have predicted that population would explode or know what the probability of such a "regime" was. No one could have known that the progress function would continue to make research so productive of technological advances. This reminds us that Knightian uncertainty hangs over most anything of importance and that centuries of underforecasting can occur.

"Research" and "technology" here are less narrow than they might be supposed. The technology includes the original screenplays that pile up at MGM, from which future movies can be made, and the inventions of Wagner and Stravinsky, which subsequent composers draw on. Yet there are two limitations of the focus on "research." One, which I was well aware of in the 1960s, was that new technologies are not costlessly absorbed into the market economy, so the link from invention to innovation is not prompt or reliable. It takes a Schumpeter-type entrepreneur to solve the problems in developing and marketing an innovation; it takes Nelson-Phelps managers to solve the problem of evaluating the innovation's likely gains, if any; it takes Amar Bhidé-type consumers to solve the problem of evaluating the gains, if any, of bringing an innovation home; and it takes Marschak-Nelson financiers who can do better than choosing randomly in deciding which entrepreneurs to back. In sum, it takes a whole village for an innovation to be developed, launched, and adopted.

The paper by Richard R. Nelson and Phelps (1966) was not written in the terminology of Ellsberg and the Savage axioms but it is about 
ambiguity. The manager of a vineyard confronting a new insecticide might have no idea what the "expected value" of the benefit and the cost of using a new insecticide would be-or what the probability of successful adoption would be-if he lacked an education in basic science and humanities. A modicum of knowledge of engineering, chemistry, and other fields improves a manager's ability to evaluate a new product or technique and thus bolsters the manager's confidence enough to encourage him to evaluate innovations that he would otherwise ignore. ${ }^{30}$

In Phelps $(2000,2005)$ I argued that continental Europe is underprepared to be a launch pad for novel innovations such as those of the Internet revolution by a dearth of Nelson-Phelps-type managers - and of venturesome Bhidé-type consumers-owing to the scarcity of university educations. (How then did the Continent latch on to the American things during its Glorious Years? Those things were too old to be still very novel.) Similarly, Bhidé and Phelps (2005) argue that the vast learning that managers and consumers have to do is a drag on successful innovation in China. Otherwise, investment and consumer demand would both be stronger, the current account surplus smaller, and growth faster.

The other severe limitation of the research view was, of course, that business people are the conceivers of the bulk of the innovations of a capitalist economy. Capitalism is Hayek country. In such an economy, Hayek says, there is a "division of knowledge" among different persons-not only dispersed information ("knowledge of current prices") but,

\footnotetext{
${ }^{30}$ The paper was ignored during the reign of rational expectations dating from the mid 1970s. But "a few good men" bent on understanding the world took it up (Robert J. Barro and Xavier Sala i Martin 1997; Philippe Aghion and Peter Howitt 1998). Results from regressions run by Jess Benhabib and Mark M. Spiegel (1994) also revived the Nelson-Phelps thesis. There, a crude version of NelsonPhelps, in which all education (even primary schooling) is useful for evaluating and absorbing innovations defeated the Becker-Mincer thesis that all education (even college education) belongs in the production function as an augmenter of raw labor input. The glory did not last long, as Alan B. Krueger and Mikael Lindahl (2001) found mistakes and concluded that Nelson-Phelps did not work well in Europe in the postwar era. I reply that the Continent had little real novelty to cope with when it was catching up with U.S. technology in the 1960s and 1970s, so no Nelson-Phelps managers were required. Moreover, it is college education that is crucial for catch-up, not total education.
}

crucially, dispersed know-how about "how commodities can be obtained and used"31 (Hayek 1937). Hayekian entrepreneurs are constantly striving to expand their knowledge into some area where knowledge is scarce or nonexistent in order to see whether they might develop something commercially saleable that no one else has conceived before. This is creativity-acquiring ideas that no one else has (or likely will have without doing the necessary exploration). Later he sketched a model of how the entrepreneur, not really knowing its commercial value, has to launch the innovation on the market to "discover" its value, if any ${ }^{32}$ (Hayek 1968).

I have tried in recent years to elaborate and apply Hayek's theory of innovation. A recent paper formalizes the theory of innovation with the theoretical device of a periodic fair in which entrepreneurs and financiers meet and enter into matches despite incomplete information (Phelps 2006d). I have also been fortunate in coming up with some empirical findings: the presence or absence of important financial institutions, such as the stock market, appears to be quite important for the readiness of an economy to seize an innovative opportunity (Phelps and Zoega 2001). Furthermore, various attributes of a country's economic culture serve to animate entrepreneurs and, more broadly, to encourage them by offering them a willing workforce and a receptive marketplace for their innovations (Phelps 2006a, see Tables 1, 2a, $2 \mathrm{~b}$, and 3 ). The direction in which I have mainly gone is to argue that, in advanced economies at any rate, innovation mechanism and discovery largely shape the experience and the rewards of participating in the economy.

\section{The Good Economy: Innovative and Inclusive}

My interest in the modern economy and my familiarity with some existing wisdom on human

\footnotetext{
${ }^{31}$ Intertemporal equilibrium, he adds, probably unnecessarily, entails that the expectations inevitably formed by firms be consistent, but does not entail that all valuable knowledge has been obtained.

${ }^{32}$ To embroider a little a remark by Amar Bhidé, the Schumpeterian chef works away in his kitchen to zero in on the exact recipe that fills the bill while the Hayekian chef, having little idea of what diners would like, experiments on his customers (see Hayek 1961 and 1968 lecture).
} 
Table 1 -Classical Wants, or Values, at Work

(Percentage of respondents reporting each want)

\begin{tabular}{lccccc}
\hline \hline & $\begin{array}{c}\text { Opportunities } \\
\text { for initiative }\end{array}$ & $\begin{array}{c}\text { Interesting } \\
\text { work }\end{array}$ & $\begin{array}{c}\text { Taking } \\
\text { responsibility }\end{array}$ & Taking orders & $\begin{array}{c}\text { Competing } \\
\text { with others }\end{array}$ \\
\hline United States & $52 \%$ & $69 \%$ & $61 \%$ & 1.47 & 1.11 \\
Canada & $54 \%$ & $72 \%$ & $65 \%$ & 1.34 & 1.01 \\
Great Britain & $45 \%$ & $71 \%$ & $43 \%$ & 1.32 & 0.57 \\
France & $38 \%$ & $59 \%$ & $58 \%$ & 1.19 & 0.67 \\
Italy & $47 \%$ & $59 \%$ & $54 \%$ & 1.04 & 0.48 \\
Germany & $59 \%$ & $69 \%$ & $57 \%$ & 1.13 & 1.21 \\
G7 ex Japan & $49 \%$ & $67 \%$ & $56 \%$ & 1.21 & 0.8 \\
\hline
\end{tabular}

Notes: Survey results from World Values Survey, Ronald Inglehart et al. "Taking orders" and "competing with others" are measured on a scale from 0 to 2,2 being the highest.

fulfillment have drawn me in the past couple of decades to the question of the good economy. This was not entirely new territory for me. In showing that "statistical discrimination," which deprives individuals of opportunities and weakens their incentives to prepare and to excel, is all too natural in the presence of information costs, I was suggesting that it is hard to prevent stereotyping and that an ideal economy is out of reach (Phelps 1972c). In some work on morality in markets, I argued that a little altruism inhibits various antisocial acts that, owing to asymmetric information, the market mechanism and legislation cannot prevent (Phelps 1973). The book by John Rawls (1971) stimulated me to expound to economists his conception of "economic justice" (Phelps 1973a; Phelps 1985) and to apply (he preferred "test") that conception in imperfect-information models of taxation (Phelps 1973b; Janusz A. Ordover and Phelps 1975). As noted, these ideas in every case hinged on one or another informational imperfection. Yet all these models and Rawls's model of the economy, too, took an austere view of the sources of human satisfaction, a view inherited from classical economics. These and other classical models left us without conceptions of the good economy suitable to modern possibilities.

It is axiomatic that one's conception of the good economy depends upon one's conception of the good life. For John Calvin (1536), the good life consisted of hard work and wealth accumulation. For Hayek (1944) and Friedman (1962), the good life was a life of freedom. The appeal of work and of freedom may be that they are necessary for a good life. ${ }^{33}$ But what is its substance, its essence?

\footnotetext{
${ }^{33}$ In any case, these conceptions of the good economy are not rich enough to provide a political economy for our
}

In a 2003 conference, I proposed that a career of challenge and personal development is the essence of the good life (Phelps 2007). It was commented that this is a "very American" view. In replying, I began to remember that this view is the classical theory of what the good life is, a theory that originated in Europe: Aristotle declared that people everywhere wanted to expand their horizons and "discover their talents." The Renaissance figure Benvenuto Cellini described the joys of creativity and "making it" in his autobiography. In Baroque times Miguel de Cervantes and William Shakespeare dramatize the individual's quest—a moral view Jacques Barzun and Harold Bloom call vitalism. Such a view is reflected to a degree by Thomas Jefferson and Voltaire among other Enlightenment figures and is interpreted by the pragmatist philosophers William James and Henri Bergson. ${ }^{34}$ The "self-actualization" in Abraham Maslow and "self-realization" in Rawls both refer to all of this, as do the "capabilities" and "doing things" in Amartya Sen (1995). This concept of human fulfillment obviously differs from Jeremy Bentham's theory of happiness, or "felicity," and it need not correlate with reported happiness. ${ }^{35}$

times. Calvinism appears consistent with a property-owning market socialism. Aside from Friedman's negative income tax and middle-Hayek's several exceptions, both of them appeared more enthusiastic about a free market economysmall government and atomistic competition-than the speculative swings and gleeful commercialism of today's capitalism (in those places where it thrives).

${ }^{34}$ The French philosopher Henri Bergson rose to fame in the years just before the Great War with his book affirming "becoming" over "being" and free will over determinism.

${ }^{35}$ I know that recent researchers on happiness find that after a certain level, nations would not gain added happiness by accumulating greater wealth with which to earn greater income. (That sounds a bit like the golden rule of asset 
Table 2A-Pride and Satisfaction Derived from the Job (on a Scale of 1-10) and the Number Reported SATISFIED (IN PERCENT)

\begin{tabular}{lccccc}
\hline \hline & $\begin{array}{c}\text { Job involvement } \\
\text { (pride derived } \\
\text { from the job) }\end{array}$ & $\begin{array}{c}\text { Job } \\
\text { satisfaction }\end{array}$ & $\begin{array}{c}\text { Feel satisfied } \\
\text { with life }\end{array}$ & $\begin{array}{c}\text { Feel satisfied } \\
\text { with home life }\end{array}$ & $\begin{array}{c}\text { Implied satisfaction } \\
\text { with life outside } \\
\text { home }\end{array}$ \\
\hline United States & 9.7 & 7.8 & $81 \%$ & $87 \%$ & $75 \%$ \\
Canada & 9.0 & 7.9 & $84 \%$ & $89 \%$ & $79 \%$ \\
Great Britain & 9.3 & 7.4 & $74 \%$ & $85 \%$ & $63 \%$ \\
France & 5.7 & 6.8 & $59 \%$ & $81 \%$ & $61 \%$ \\
Italy & 6.7 & 7.3 & $71 \%$ & $76 \%$ & $66 \%$ \\
Germany & 6.0 & 7.0 & $71 \%$ & $62 \%$ & $44 \%$ \\
Japan & 7.3 & NA & $53 \%$ & & $61 \%$ \\
\hline
\end{tabular}

Note: Survey results from Human Beliefs and Values Survey, Inglehart et al.

Table 2B-Circumstantial Evidence and Other Performance Indicators

\begin{tabular}{lccccc}
\hline \hline & $\begin{array}{c}\text { Male labor force } \\
\text { in \% of } \\
\text { working-age } \\
\text { men, 2003 }\end{array}$ & $\begin{array}{c}\text { Female labor force } \\
\text { in \% of } \\
\text { working-age } \\
\text { women, 2003 }\end{array}$ & $\begin{array}{c}\text { Employment in } \\
\% \text { of the labor } \\
\text { force 2003 }\end{array}$ & $\begin{array}{c}\text { Labor } \\
\text { compensation } \\
\text { per worker 1996 }\end{array}$ & $\begin{array}{c}\text { Market output } \\
\text { per hour in } \\
1992\end{array}$ \\
\hline United States & $85 \%$ & $70 \%$ & $94 \%$ & $\$ 31,994$ & 100 \\
Canada & $85 \%$ & $69 \%$ & $92 \%$ & $\$ 23,751$ & -13 \\
Great Britain & $85 \%$ & $67 \%$ & $95 \%$ & $\$ 22,008$ & 92 \\
France & $76 \%$ & $61 \%$ & $90 \%$ & $\$ 24,192$ & - \\
Italy & $76 \%$ & $45 \%$ & $91 \%$ & $\$ 21,822$ & 92 \\
Germany & $79 \%$ & $62 \%$ & $91 \%$ & $\$ 23,946$ & 73 \\
\hline
\end{tabular}

Notes: Men in the labor force in \% of working age men and employment in \% of the labor force are computed for 2003 (OECD); labor compensation per worker is computed as the ratio of total compensation to the labor force using 1996 data (Extended Penn World Tables); market output per hour worked is for 1992 (Solow and Baily 2001).

TABLE 3-MeAsures of THE ECONOMY's DynAmism

\begin{tabular}{lcccc}
\hline \hline & $\begin{array}{c}\text { Decision-making } \\
\text { freedom at work }\end{array}$ & $\begin{array}{c}\text { Turnover of } \\
\text { listed firms }\end{array}$ & $\begin{array}{c}\text { Patents granted } \\
\text { per working } \\
\text { age person }\end{array}$ & $\begin{array}{c}\text { R\&D intensity } \\
\text { adjusted for } \\
\text { industry structure }\end{array}$ \\
\hline United States & 7.4 & $118 \%$ & 3.7 & 2.9 \\
Canada & 7.2 & $106 \%$ & 1.3 & 1.8 \\
Great Britain & 7.0 & $65 \%$ & 0.8 & 1.9 \\
France & 6.4 & $79 \%$ & 0.9 & 2.2 \\
Italy & 6.7 & $63 \%$ & 0.4 & 1.0 \\
Germany & 6.1 & $42 \%$ & 1.5 & 2.2 \\
\hline
\end{tabular}

Notes: "Decision-making freedom at work" is measured on a scale from 1 to 10, 10 highest, averaged for 1990-1993 (Human Beliefs and Values, Inglehart et al.); "turnover of listed firms" represents the number of exits from and entries into each country's MSCI National Stock Index from 2001 to 2006 as a \% of the number of firms in 2001; patenting data are averaged for 1990-2003 (World Intellectual Property Organization); "R\&D intensity adjusted for industry structure" is the average \% of business sector value added for 1999-2002 using the G7 industry structure (OECD).

If that is the substance of the good life, it appears that a good economy promotes "vitalist" lives. It produces the stimulation, challenge, engagement, mastery, discovery, and development that constitute the good life.
There are also the claims of justice. The disadvantaged have a right to inclusion in the economy and thus also in society. In the perspective of Rawls (1971), inclusion means that the least advantaged toil in the formal economy 
under terms affording them prospects of selfrealization-their pay good enough (and their joblessness infrequent enough) to permit them to function as spouses, parents, citizens, and community members. Rawls's economics, being largely classical, left no room for selfrealization obtained from business life. In my discussion, I say that many and perhaps most people draw deep satisfaction from taking part in what is the central institution of an economically advanced society, namely its business economy, and that for minorities such employment is the spine of social integration (Phelps 1997). Moreover, in a society having a vitalist work culture that values mental challenge, organizational responsibility and individual initiative, it is not impossible that even low-end employment contributes to self-realization; so a high degree of inclusion may be all the more valuable in an economy offering vitalist careers. (What I say below does not hinge on that.) In short, a good economy also promotes inclusion.

A country can promote both vitality and inclusion by fitting its economy with the right mechanisms. Our theoretical understanding of modern economies, its rudimentary state notwithstanding, and the bulk of empirical evidence strongly suggest that careers of vitality require an economy generating change and a generally forward motion; and such economic dynamism is best served by a system of institutions and mechanisms like capitalism-regulated and deregulated as required in order to provide a high rate of commercially successful innovation of noncoordinated entrepreneurs, financiers, and consumers. Our theoretical understanding of incentive design and empirical observation strongly suggest that inclusion is most effectively served by fiscal incentives-a system of public low-wage employment subsidies as well as classical education subsidies in order to attract marginalized workers to the business sector, shrink their unemployment rates, and boost their pay. ${ }^{36}$

accumulation.) That finding, whether or not it will stand up, does not imply that there is some satiation level of the classical gratifications. It suggests only that, after a point, higher income does not boost satisfaction of the classical wants.

${ }^{36}$ Rawls (1971) argues for going in this direction to the greatest possible extent. I would inject here that Rawlsian
Are vitality and inclusion incompatible, gains in the one undoing gains in the other? Two fallacies here have gotten in the way of consensus for action. In the West, it is believed by many, with no foundation I know of, that a fiscal policy aimed at broad economic inclusion would substantially preclude ample economic dynamism and thus a vitalist society. I have argued that, on the contrary, suitably designed employment subsidies would restore the bourgeois culture, revive the ethic of self-support, and increase prosperity in low-wage communities. That would boost a country's dynamism, not weaken it, and also strengthen popular support for capitalist institutions (Phelps 1997).

It is believed by a many others that the dynamism of an entrepreneurial economy harms disadvantaged workers. I argue that economic dynamism works to raise inclusion. Heightened entrepreneurial activity indirectly lifts up both those already enjoying much of the good life and - up to a point, at any rate-disadvantaged workers, too, taken as a group. The resulting dynamism, the stepped-up rate of commercially successful innovation, creates jobs in new activities and in so doing it draws the disadvantaged into better work and higher pay. A look at the experience around us in the present decade suggests that the disadvantaged have suffered an acute failure of inclusion in economies that are resistant to innovation. Heightened entrepreneurship also tends to serve the disadvantaged directly by making their jobs less burdensome and dangerous - and perhaps also more engaging. An innovative economy is not unjust, since it helps the disadvantaged as well as the advantaged (Phelps 2007).

Now, in Europe, a great many countries are searching for a route to greater general prosperity and greater economic inclusion of disadvantaged groups. There is a debate in the making between, on the one hand, those neoclassicals who would put the emphasis on pushing more resources into the economy (more technology or more human capital) as a way of raising output and employment; and, on the other hand, those modernizers who favor a strategy of pulling

justice in a modern economy must consider the prospects for self-realization of entrepreneurial types as well as the lowest-wage workers. But I will not defend that here. 
existing resources into innovative activity and general business activity through reforms of labor law, company law, and the financial sector.

My conclusion is that a morally acceptable economy must have enough dynamism to make work amply engaging and rewarding; and have enough justice, if dynamism alone cannot do the job, to secure ample inclusion.

\section{REFERENCES}

Aghion, Philippe, Roman Frydman, Joseph Stiglitz, and Michael Woodford. 2003. "Edmund S. Phelps and Modern Macroeconomics." In Knowledge, Information, and Expectations in Modern Macroeconomics: In Honor of Edmund S. Phelps, ed. Philippe Aghion, Roman Frydman, Joseph Stiglitz, and Michael Woodford, 3-22. Princeton: Princeton University Press.

Aghion, Philippe, and Peter Howitt. 1998. Endogenous Growth Theory. Cambridge, MA: MIT Press.

Barro, Robert J., and Xavier Sala-i-Martin. 1997. "Technological Diffusion, Convergence, and Growth." Journal of Economic Growth, 2(1): $1-26$.

Barzun, Jacques. 1962. "From the Nineteenth Century to the Twentieth." In Chapters in Western Civilization, Vol. II, ed. Contemporary Civilization Staff of Columbia College, 441-64. New York: Columbia University Press.

Barzun, Jacques. 2000. From Dawn to Decadence: 500 Years of Western Cultural Life. New York: HarperCollins.

Benhabib, Jess, and Mark M. Spiegel. 1994. "The Role of Human Capital in Economic Development: Evidence from Aggregate CrossCountry Data." Journal of Monetary Economics, 34(2): 143-73.

Bergson, Henri. 1911. Creative Evolution. Trans. Arthur Mitchell. New York: Henry Holt.

Bhidé, Amar, and Edmund S. Phelps. 2005. "A Dynamic Theory of China-U.S. Trade," Center on Capitalism and Society Working Paper 04.

Bloom, Harold. 1994. The Western Canon: The Books and School of the Ages. New York: Harcourt Brace.

Bloom, Harold. 2002. Genius: A Mosaic of One Hundred Creative Minds. New York: Warner Books.
Calvin, John. 1536. Institutes of the Christian Religion. Trans. Henry Beveridge. Repr. Grand Rapids, MI: W.B. Eerdmans Publishing Company, 1975.

Calvo, Guillermo A., and Edmund S. Phelps. 1977. "Indexation Issues: Appendix." Carnegie-Rochester Conference Series on Public Policy, 5: 160-68. Repr. In Edmund S. Phelps, Studies in Macroeconomic Theory, Vol.1: Employment and Inflation. New York: Academic Press, 1979.

Calvo, Guillermo, and Edmund S.Phelps. 1983. "A Model of Non-Walrasian General Equilibrium: Its Pareto Inoptimality and Pareto Improvement." In Macroeconomics, Prices and Quantities: Essays in Memory of Arthur M. Okun, ed. James Tobin. Washington, DC: Brookings Institution Press.

Dewald, William G., and Harry G. Johnson. 1963. "An Objective Analysis of the Objectives of American Monetary Policy, 1952-61." In Banking and Monetary Studies, ed. Deane Carson, 171-189. Homewood, Il: Richard Irwin.

Ellsberg, Daniel. 1961. "Risk, Ambiguity, and the Savage Axioms." Quarterly Journal of Economics, 75(4): 643-69.

Fellner, William J. 1961. "Distortion of Subjective Probabilities as a Reaction to Uncertainty." Quarterly Journal of Economics, 75(4): 670-89.

Fitoussi, Jean-Paul, David Jestaz, Edmund S. Phelps, and Gylfi Zoega. 2000. "Roots of the Recent Recoveries: Labor Market Reforms or Private Sector Forces?" Brookings Papers on Economic Activity, 1: 237-311.

Fitoussi, Jean-Paul, and Edmund S. Phelps. 1986. "Causes of the 1980s Slump in Europe." Brookings Papers on Economic Activity, 2: 487-513.

Fitoussi, Jean-Paul, and Edmund S. Phelps. 1988. The Slump in Europe: Reconstructing Open Economy Theory. Oxford: Blackwell.

Friedman, Milton. 1968. "The Role of Monetary Policy," American Economic Review, 58 (1): $1-17$.

Friedman, Milton. 1962. Capitalism and Freedom. Chicago: University of Chicago Press.

Frydman, Roman, and Edmund S. Phelps. 1983. "Introduction." In Individual Forecasting and Aggregate Outcomes: 'Rational Expectations' Examined, ed. Roman Frydman and Edumnd S. Phelps. New York: Cambridge University Press. 
Frydman, Roman, and Michael D. Goldberg. Forthcoming. Imperfect Knowledge Economics: Exchange Rates and Risk. Princeton: Princeton University Press.

Hayek, Friedrich. 1937. "Economics and Knowledge," Economica, 4(13), pp. 43-54. Repr. in Friedrich Hayek, Individualism and Economic Order. Chicago: University of Chicago Press, 1948.

Hayek, Friedrich A. 1944. The Road to Serfdom. London: Routledge.

Hayek, Friedrich. 1945. "The Use of Knowledge in Society," American Economic Review, 35(4): 519-30. Repr. in Friedrich Hayek, Individualism and Economic Order. Chicago: University of Chicago Press, 1948.

Hayek, Friedrich. 1961. "The Non Sequitur of the 'Dependence Effect,'" Southern Economic Journal, 27(4): 346-48. Repr. E. S. Phelps, ed., Private Wants and Public Needs, W.W. Norton \& Co., 1962.

Hayek, Friedrich A. 1978. "Competition as a Discovery Procedure." Repr. in Friedrich Hayek, New Studies in Philosophy, Economics and the History of Ideas. Chicago: University of Chicago Press. (Orig. pub. 1968.)

Hoon, Hian Teck. 2006. "Payroll Taxes, Wealth and Employment in Neoclassical Theory: Neutrality or Non-neutrality," Paper Presented at CESIFO-CCS Conference, Venice.

Hoon, Hian Teck, and Edmund S. Phelps. 1992. "Macroeconomic Shocks in a Dynamized Model of the Natural Rate of Unemployment." American Economic Review, 82(4): 889-900.

Hoon, Hian Teck, and Edmund S. Phelps. 1996. "Payroll Taxes and Vat in a Labor-Turnover Model of the 'Natural Rate.'" International Tax and Public Finance, 3(3): 369-83.

Hoon, Hian Teck, and Edmund S. Phelps. 1997. "Growth, Wealth and the Natural Rate: Is the Jobs Crisis a Growth Crisis?" European Economic Review, 41(3-5): 549-57.

Hoon, Hian Teck, and Edmund S. Phelps. Forthcoming. "Future Fiscal and Budgetary Shocks," Journal of Economic Theory.

Inglehart, Ronald. 2006. World Values Surveys 1981-2004. Ann Arbor: University of Michigan Press.

Keynes, John Maynard. 1921. A Treatise on Probability. London: Macmillan.

Keynes, John Maynard. 1936. The General Theory of Employment, Interest and Money. London: Macmillan.
Keynes, John Maynard. 1937. "The General Theory of Employment," Quarterly Journal of Economics, 51.

Keynes, John Maynard. 1983. The Collected Works of John Maynard Keynes. London: Macmillan for the Royal Economic Society.

Knight, Frank H. 1921. Risk, Uncertainty and Profit. Boston: Houghton Mifflin.

Krueger, Alan B., and Mikael Lindahl. 2001. "Education for Growth: Why and for Whom?" Journal of Economic Literature, 39(4): 1101-36.

Laibson, David. 1997. "Golden Eggs and Hyperbolic Discounting." Quarterly Journal of Economics, 112(2): 443-77.

Lucas, Robert E., Jr. 1972. "Expectations and the Neutrality of Money." Journal of Economic Theory, 4(2): 103-24.

Lucas, Robert E., Jr. 1976. "Econometric Policy Evaluation: A Critique." Carnegie-Rochester Conference Series on Public Policy, 1: 19-46.

Lucas, Robert E., Jr., and Leonard A. Rapping. 1969. "Real Wages, Employment, and Inflation." Journal of Political Economy, 77(5): 721-54.

Marshall, Alfred. 1892. Elements of Economics. London: Macmillan.

Merton, Robert K. 1936. "The Unanticipated Consequences of Purposive Social Action." American Sociological Review, 1(6): 894904.

Myrdal, Gunnar. 1932. The Political Element in the Development of Economic Theory. Trans. by Paul Streeten. Repr., London: Routledge, 1953.

Nelson, Richard R. and Phelps, Edmund S. 1966. "Investment in Humans, Technological Diffusion, and Economic Growth," American Economic Review, 56(2): 69-75. Repr. in Ronald A. Wykstra, ed., Human Capital Formation and Manpower Development. New York: Free Press, 1971.

Okun, Arthur M., ed. 1965. The Battle against Unemployment. New York: W. W. Norton and Company.

Ordover, Janusz. A., and Edmund S. Phelps. 1975. "Linear Taxation of Wealth and Wages for Intragenerational Lifetime Justice: Some Steady-State Cases." American Economic Review, 65(4): 660-73.

Phelps, Edmund S. 1961. "The Golden Rule of Accumulation: A Fable for Growthmen." American Economic Review, 51 (4): 638-43. 
Phelps, Edmond S. 1962. "The Accumulation of Risky Capital." Econometrica, 30(4): 72943.

Phelps, Edmund S. 1965. Fiscal Neutrality toward Economic Growth. New York: McGraw-Hill.

Phelps, Edmund S. 1966a. Golden Rules of Economic Growth. New York: W.W. Norton and Company.

Phelps, Edmund S. 1966b. "Models of Technical Progress and the Golden Rule of Research," Review of Economic Studies, 33(2): 133-45.

Phelps, Edmond S. 1966c. "Optimal Employment and Inflation over Time." Yale University, Cowles Foundation Discussion Paper 214.

Phelps, Edmund S. 1967. "Inflation Expectations and Optimal Unemployment over Time." Economica, 34(135): 254-81.

Phelps, Edmund S. 1968a. "Money Wage Dynamics and Labor Market Equilibrium." Journal of Political Economy, 76(4): 687711. Repr. in Panayotis G. Korliras and Richard S. Thorn, eds., Modern Macroeconomic: Major Contributions to Contemporary Thought. New York: Harper and Row, 1979.

Phelps, Edmund S. 1968b. "Population Increase." Canadian Journal of Economics,1(3): 497-518.

Phelps, Edmund S. 1972a. Inflation Policy and Unemployment Theory. New York: W. W. Norton and Company.

Phelps, Edmund S. 1972b. "Money, Public Expenditure and Labor Supply." Journal of Economic Theory, 5(1): 69-78.

Phelps, Edmund S. 1972c. "The Statistical Theory of Racism and Sexism." American Economic Review, 62(4): 659-61.

Phelps, Edmund S., ed. 1973a. "Introduction." In Economic Justice. Harmondsworth, UK: Penguin Books.

Phelps, Edmund S. 1973b. "Taxation of Wage Income for Economic Justice." Quarterly Journal of Economics, 87(3): 331-54.

Phelps, Edmund S. 1978. "Disinflation without Recession: Adaptive Guideposts and Monetary Policy," Weltwirtschaftliches Archiv, 100(2). Repr. in Edmund S. Phelps, Studies in Macroeconomic Theory. Vol. 1: Employment and Inflation. New York: Academic Press, 1979.

Phelps, Edmund S., ed. 1979. "Introduction: Developments in Non-Walrasian Theory," In
Studies in Macroeconomic Theory, Volume 1: Employment and Inflation. New York: Academic Press.

Phelps, Edmund S. 1983. "The Trouble with Rational Expectations and the Problem of Inflation Stabilization," In Individual Forecasting and Aggregate Outcomes: 'Rational Expectations' Examined, ed. Roman Frydman and Edmund S. Phelps. Cambridge: Cambridge University Press.

Phelps, Edmund S. 1985. Political Economy: An Introductory Text. New York: W. W. Norton and Company.

Phelps, Edmund S. 1992. "Consumer Demand and Equilibrium Unemployment in a Working Model of the Customer-Market Incentive-Wage Economy." Quarterly Journal of Economics, 107(3): 1003-32.

Phelps, Edmund S. 1994. Structural Slumps: The Modern Equilibrium Theory of Unemployment, Interest, and Assets. In collaboration with Hian Teck Hoon, George Kanaginis, and Gylfi Zoega. Cambridge, MA: Harvard University Press.

Phelps, Edmund S. 1997. Rewarding Work: How to Restore Participation and Self-Support to Free Enterprise. Cambridge MA: Harvard University Press.

Phelps, Edmund S. “Europe's Stony Grounds for the Seeds of Growth." Financial Times, August 9, 2000.

Phelps, Edmund S. 2006a. "Economic Culture and Economic Performance: What Light is Shed on the Continent's Problem?" Paper presented at the CESIFO-CCS Conference, San Servolo, Venice.

Phelps, Edmund S. 2006b. "Employment, Asset Prices and Monetary Policy," Paper presented at the Festschrift for Axel Leijonhufvud, UCLA, Los Angeles, CA.

Phelps, Edmund S. 2006c. "Prospective Shifts, Speculative Swings: 'Macro' for the TwentyFirst Century in the Tradition Championed by Paul Samuelson." In Samuelsonian Economics and the Twenty-First Century, ed. Michael Szenberg, Lall Ramrattan, and Aron A. Gottesman. Oxford: Oxford University Press.

Phelps, Edmund S. 2006d. "Toward a Model of Innovation and Performance: Along the Lines of Knight, Keynes, Hayek and M. Polanyí." Paper presented at the Max Planck Institut-Kauffman Foundation Conference, Tegernsee, Munich. 
Phelps, Edmund S. 2006e. "Understanding the Great Changes in the World: Gaining Ground and Losing Ground since World War II." Lecture, International Economic Association World Congress, Marrakech, August 28-September 2, 2005. Capitalism and Society, 1(2), 2006. Electronic journal of the Center on Capitalism and Society, BE Press.

Phelps, Edmund S. 2007. "The Economic Performance of Nations: Prosperity Depends on Dynamism, Dynamism on Institutions." Conference on Entrepreneurship, Innovation and the Growth Mechanism of the Free-Market Economies (Nov. 2003). In Eytan Sheshinski, ed., The Growth Mechanism of Free Enterprise Economies, Princeton: Princeton University Press.

Phelps, Edmund S., et al. 1970. Microeconomic Foundations of Employment and Inflation Theory. New York: W. W. Norton and Company.

Phelps, Edmund S., and Robert A. Pollak. 1968. "Second-Best National Saving and GameEquilibrium Growth." Review of Economic Studies, 35(2):185-99.

Phelps, Edmund S., and John B. Taylor. 1977. "Stabilizing Powers of Monetary Policy Under Rational Expectations." Journal of Political Economy, 85(1): 163-90.

Phelps, Edmund S., and Sidney G. Winter, Jr., 1970. "Optimal Price Policy under Atomistic Competition." In Microeconomic Foundations of Employment and Inflation Theory, ed. Edmund S. Phelps et al. New York: W. W. Norton and Company.

Phelps, Edmund S., and Gylfi Zoega. 1997. "The Rise and Downward Trend of the Natural Rate." American Economic Review, 87(2): 283-89.

Phelps, Edmund S., and Gylfi Zoega. 1998. "Natural-Rate Theory and OECD Unemployment." Economic Journal, 108(448): 782-801.

Phelps, Edmund S., and Gylfi Zoega. 2001. "Structural Booms." Economic Policy: A European Forum, 32: 83-114.

Phelps, Edmund S., Hian Teck Hoon, and Gylfi Zoega. 2005. "The Structuralist Perspective on Real Exchange Rate, Share Price Level and Employment Path: What Room is Left for Money?" In Monetary Policy and Unemployment: the U.S., Euro-Area and Japan, ed. Willi Semmler, 107-32. London: Routledge.
Phillips, Alban William. 1958. "The Relation between Unemployment and the Rate of Change of Money Wage Rates in the United Kingdom,1861-1957." Economica, 25(100): 83-99.

Pissarides, Christopher. Quoted in The Independent, London, October 10, 2006.

Ramsey, Frank P. 1928. "A Mathematical Theory of Saving." Economic Journal, 38(152): 543-59.

Rawls, John. 1971. A Theory of Justice. Cambridge, MA: Harvard University Press.

Salop, Steven C. 1979. "A Model of the Natural Rate of Unemployment." American Economic Review, 69(1): 117-25.

Samuelson, Paul A. 1947. Foundations of Economic Analysis. Cambridge, MA: Harvard University Press.

Samuelson, Paul A. 1948. Economics: An Introductory Analysis. New York: McGraw-Hill.

Samuelson, Paul A. Quoted in Chicago SunTimes, Chicago, October 10, 2006.

Sargent, Thomas J. 1999. The Conquest of American Inflation. Princeton: Princeton University Press.

Sen, Amartya. 1995. Inequality Reexamined. New York: W. W. Norton and Company.

Shapiro, Carl, and Stiglitz, Joseph E. 1984 "Equilibrium Unemployment as a Worker Discipline Device." American Economic Review, 74(3): 433-44.

Solow, Robert M., and Martin N. Bailey. 2001. "International Productivity Comparisons Built from the Firm Level." Journal of Economic Perspectives, (15)3: 151-72.

Taylor, John B. 1993. "Discretion versus Policy Rules in Practice." Carnegie-Rochester Conference Series on Public Policy, 39(0): 195-214.

Taylor, John B. ed. 1999. Monetary Policy Rules. Chicago: University of Chicago Press.

Tobin, James. 1975. "Keynesian Models of Recession and Depression." American Economic Review, 65(2): 195-202.

Tönnies, Ferdinand. 1887. Gemeinschaft und Gesselschaft. Vienna.

Weber, Max. 1921-22. Economy and Society. Trans. of Wirtschaft und Gesellschaft. Berekely: University of California Press, 1978.

Zoega, Gylfi. 1993. A Structural Model of Equilibrium Unemployment: Theory, Empirical Testing and Dynamic Simulation. PhD diss. Coumbia University. 